\title{
ANALISIS DPK, CAR, ROA DAN NPF TERHADAP PEMBIAYAAN PADA PERBAN KAN SYARIAH
}

\author{
N unimansyah Setivia Bakti \\ PT Bank Mualamat \\ nurimansyah.bakti@ bankmuamalat.co.id
}

\begin{abstract}
This research attempts to analyze the factors that affect the financing of Islamic banking in Indonesia. The independent variable in this study is the Third Party Funds (TPF), Capital Adequacy Ratio (CAR), Return on Assets (ROA), Non Performing Financing (NPF). The sample used in this study were all population numbering Islamic Banks Islamic Banks 11. The data used in this study were obtained from published financial statements by Islamic Banks with the observation period 2013 to 2016. Based on the research result that the $F$ test is declare that all the independent variables (independent) consisting of Third Party Funds (TPF), Capital Adequacy Ratio (CAR), Return on Assets (ROA) and Non-Performing Financing (NPF) have a significant effect on the Financing of Islamic Banks. At t test, Third Party Funds (TPF) influence and significant to financing, the Capital Adequacy Ratio (CAR) and Return on Assets (ROA) have no significant effect on financing, while NPF has negative influence and insignificant effect on financing.
\end{abstract}

Keywords: Financing, Third Party Funds (TPF), Capital Adequacy Ratio (CAR), Return on Assets (ROA) and Non Performing Financing (NPF)

\begin{abstract}
ABSTRAK
Penelitian ini mencoba untuk menganalisa faktor-faktor yang mempengaruhi pembiayaan pada perbankan syariah di Indonesia. Variabel bebas dalam penelitian ini adalah Dana Pihak Ketiga (DPK), Capital Adequacy Ratio (CAR), Return On Assets (ROA), Non Performing Financing (NPF). Sampel yang digunakan dalam penelitian ini adalah semua populasi Bank Umum Syariah yang berjumlah 11 Bank Umum Syariah. Data yang dipergunakan dalam penelitian ini diperoleh dari laporan keuangan yang dipublikasikan oleh Bank Umum Syariah dengan masa pengamatan 2013 sampai 2016. Berdasarkan penelitian diperoleh hasil bahwa uji $\mathrm{F}$ yang dilakukan menyatakan bahwa semua variabel bebas (independen) yang terdiri dari Dana Pihak Ketiga (DPK), Capital Adequacy Ratio (CAR), Return On Assets (ROA), Non Performing Financing (NPF) berpengaruh signifikan terhadap pembiayaan Bank Umum Syariah. Pada uji t, Dana Pihak Ketiga (DPK) pengaruh dan signifikan terhadap pembiayaan, Capital Adequacy Ratio (CAR), Return On Assets (ROA) berpengaruh tidak signifikan terhadap pembiayaan, sedangkan NPF mempunyai pengaruh negative dan tidak signifikan terhadap pembiayaan.
\end{abstract}

Kata Kunci : Pembiayaan, Dana Pihak Ketiga (DPK), Capital Adequacy Ratio (CAR), Return On Assets (ROA) dan Non Performing Financing (NPF) 
Industri perbankan sebagai lembaga mediasi sektor keuangan merupakan bagian penting dalam perekonomian mengingat perannya sebagai perantara keuangan yang mempertemukan pihak yang membutuhkan dana dengan pihak yang kelebihan dana. Mediasi keuangan pada sektor perbankan tentu sangat penting bagi setiap negara termasuk Indonesia.Di Indonesia sistem perbankan yang digunakan adalah dual banking sistem dimana beroperasi dua jenis usaha bank yaitu bank syariah dan bank konvensional sejak diberlakukanya UU no. 10 tahun 1998.Berdasarkan laporan dari OJK per Juni 2015, industri perbankan syariah terdiri dari 12 Bank Umum Syariah, 22 Unit Usaha Syariah yang dimiliki oleh Bank Umum Konvensional dan 162 BPRS dengan total aset sebesar Rp. 273,494 Triliun dengan pangsa pasar 4,61\%. Khusus untuk wilayah Provinsi DKI Jakarta, total aset gross, pembiayaan, dan Dana Pihak Ketiga(BUS dan UUS) masing-masing sebesar Rp. 201,397 Triliun, Rp. 85,410 Triliun dan Rp. 110,509 Triliun. Sejarah kemunculan lembaga keuangan syariah modern dimulai tahun 1990-an ditandai dengan berdirinya Bank Muamalat Indonesia pada tahun 1992.

Perkembangan perbankan syariah dimulai dengan disetujuinya Undang-Undang yaitu UU No 10 tahun 1998.Undang-undang tersebut juga memberikan dorongan kepada bank-bank konvensional untuk membuka unit syariah atau bahkan mengkonversikan diri menjadi bank syariah.Sejalan dengan hal tersebut maka berdirilah bank syariah yang merupakan bank yang melaksanakan secara utuh kegiatan usaha berdasarkan prinsip syariah.Melalui UU No. 23 tahun 1999, pemerintah memberikan kewenangan kepada Bank Indonesia untuk dapat menjalankan tugasnya berdasarkan prinsip syariah. Selanjutnya adalah Undang-Undang Perbankan Syariah Nomor 21 Tahun 2008 menerangkan bahwa perbankan syariah adalah segala sesuatu yang menyangkut tentang Bank Syariah dan Unit Usaha Syariah, mencakup kelembagaan, kegiatan usaha, serta tata cara dan proses dalam melaksanakan kegiatan usahanya. Dengan terbitnya Undang-Undang Perbankan Syariah Nomor 21 Tahun 2008 diharapkan menjadi payung hukum yang lebih kompleks dalam mendorong pertumbuhan perbankan syariah yang lebih cepat.

Pada tahun 2014 perkembangan industri perbankan Indonesia telah mencapai 12 Bank Umum Syariah. Bank Umum Syariah yang beroperasi di Indonesia, diantaranya Bank Muamalat Indonesia, Bank Syariah Mandiri (BSM), Bank Mega Syariah (BMS), BRI Syariah, Bank Bukopin Syariah, Bank Panin Syariah, Bank Victoria Syariah, BCA Syariah, Bank Jabar dan Banten Syariah, Bank Syariah BNI, May Bank Indonesia Syariah dan terakhir pada akhir Juli 2014 berdiri PT. Bank Tabungan Pensiunan Nasional Syariah.

Seperti halnya perbankan umum lainnya bank syariahdalam menyalurkan pembiayaan juga mempertimbangkan faktor internal perbankan dan eksternal perbankan. Hal ini senada dengan pernyataan Muljono (2001) bahwa besarnya kredit yang disalurkan kepada masyarakat diperngaruhi oleh faktor internal perbankan dan eksternal perbankan (makro).Hal senada juga diungkapkan oleh Osei (2013) yang meneliti faktor-faktor yang mempengaruhi pinjaman bankdiGhana, hasil dari penelitian ini bahwa ukuran bankdanstruktur modalmemiliki hubungan yangsignifikan secara statistikdanpositif denganpenyaluranpinjaman bank dan menemukan buktibahwa indikatormakroekonomi(suku bunga pinjaman bank sentral dannilai tukar) berdampak negatifdan signifikanterhadap penyaluranpinjaman bank.

\section{TELAAH PUSTAKA}

Pengertian bank menurut SAK Nomor 31 dalam Standar Akuntansi Keuangan tahun 2009 (revisi 2000) yaitu : “Bank adalah suatu lembaga yang berperan sebagai perantara keuangan antara pihak-pihak yang memiliki kelebihan dana dan pihak-pihak 
yang memerlukan dana, serta sebagai lembaga yang berfungsi memperlancar lalu lintas pembayaran".

Berdasarkan pasal 1 Undang - Undang No. 10 Tahun 1998 tentang perubahan Undang - Undang No. 7 Tahun 1992 tentang Perbankan, Bank didefinisikan sebagai berikut: Bank adalah badan usaha yang menghimpun dari masyarakat dalam bentuk simpanan dan menyalurkan kepada masyarakat. Kasmir (2004) mengatakan bank secara sederhana dapat diartikan sebagai berikut: Lembaga keuangan yang kegiatan utamanya adalah menghimpun dana dari masyarakat dan menyalurkannya kembali dana tersebut ke masyarakat serta memberikan jasa bank lainnya.

Menurut Undang-undang Nomor 21 tahun 2008 tentang perbankan syariah menyatakan bahwa Perbankan syariah adalah segala sesuatu yang menyangkut tentang Bank Syariah dan Unit Usaha Syariah, mencakup kelembagaan, kegiatan usaha, serta cara dan proses dalam melaksanakan kegiatan usahanya. Jadi Bank Syariah adalah bank yang menjalankan kegiatan usahanya berdasarkan prinsip syariah dan menurut jenisnya terdiri dari Bank Umum Syariah (BUS) dan Bank Perkreditan Rakyat Syariah (BPRS). Prinsip Syariah adalah prinsip hukum Islam dalam kegiatan perbankan berdasarkan fatwa yang dikeluarkan oleh lembaga yang memiliki kewenangan dalam penetapan fatwa dibidang syariah.

Prinsip operasional syariah yang telah ditetapkan secara luas dalam penghimpunan dana masyarakat adalah prinsip wadiah dan mudharabah (Siamat, 2001). Dengan demikian jenis penghimpunan dana di bank syariah sesuai dengan prinsip yang melandasinya. Muhammad (2001) menyatakan bahwa Pembiayaan secara luas berarti financing atau pembelanjaan, yaitu pendanaan yang dikeluarkan untuk mendukung investasi yang telah direncanakan, baik dilakukan sendiri maupun dijalankan oleh orang lain.

Dendawijaya (2005) mengatakan "Capital adequacy ratio merupakan rasio yang memperlihatkan seberapa jauh seluruh aktiva bank yang mengandung risiko (kredit penyertaan, surat berharga, tagihan pada bank lain) untuk dibiayai dari dana modal bank sendiri, disamping memperoleh dana-dana dari sumber-sumber di luar, seperti dana masyarakat, pinjaman (utang) dan lain-lain." Menurut Siamat (2004), "Non performing loan atau sering disebut kredit bermasalah dapat diartikan sebagai pinjaman yang mengalami kesulitan pelunasan akibat adanya faktor kesengajaan dan atau karena faktor eksternal di luar kemampuan kendali debitur seperti kondisi ekonomi yang buruk."

\section{Penelitian Terdahulu}

Olokoyo (2011) melakukan penelitian faktor-faktor penentu perilaku pinjaman bank komersial di Nigeria periode 1980-2005. Variabel yang digunakan adalah volume mereka deposito, portofolio investasi, suku bunga pinjaman, kas rasio cadangan kas dan rasio likuiditas. Hasil dari penelitian ini menyatakan bahwa deposito bank komersial memiliki dampak terbesar pada penyaluran pinjaman.

Ladime, Sarpong-Kumankoma, Osei (2013) meneliti faktor-faktor yang mempengaruhi pinjaman bank di Ghana. Hasil dari penelitian ini bahwa ukuran bank dan struktur modal memiliki hubungan yang signifikan secara statistik dan positif dengan penyaluran pinjaman bank dan menemukan bukti bahwa indikator makro ekonomi (suku bunga pinjaman bank sentral dan nilai tukar) berdampak negatif dan signifikan terhadap penyaluran pinjaman bank.

\section{Kerangka Pemikiran}

Berdasarkan pada landasan teori dan hasil penelitian sebelumnya serta permasalahan yang telah dikemukakan, maka sebagai dasar perumusan hipotesis berikut disajikan kerangka pemikiran yang dituangkan dalam model penelitian pada Gambar 1. 


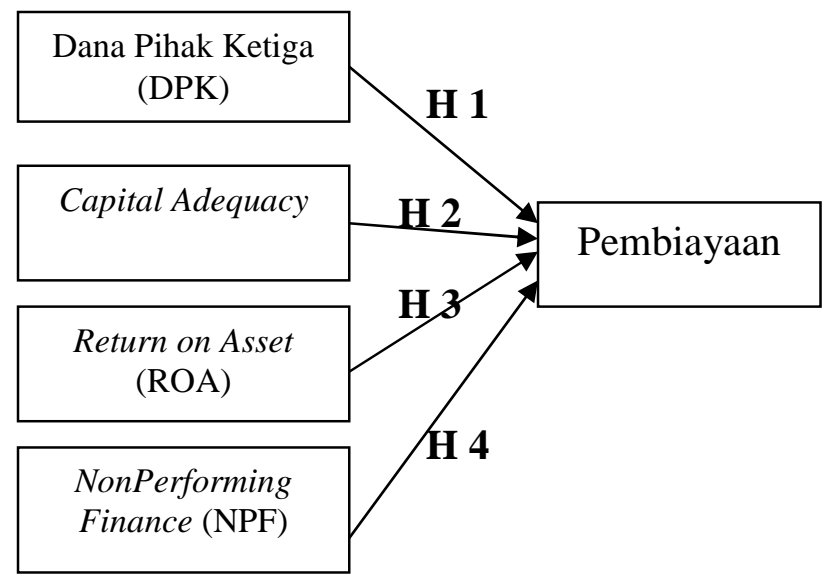

\section{Gambar 1. Kerangka Pemikiran Teoritis}

Dana Pihak Ketiga (DPK) mempunyai pengaruh positif terhadap pembiayaan yaitu jika DPK mengalami kenaikan maka akan berpengaruh pada pembiayaan yang juga mengalami kenaikan.Capital Adequacy Ratio (CAR) mempunyai pengaruh positif terhadap pembiayaan yaitu jika CAR mengalami kenaikan maka akan berpengaruh pada pembiayaan yang juga mengalami kenaikan.Return on Aseet (ROA) mempunyai pengaruh positif terhadap penyaluran pembiayaanyaitu jika ROA mengalami kenaikan maka akan berpengaruh pada pembiayaan yang juga mengalami kenaikan.Non Performing Financing (NPF) mempunyai pengaruh negatif terhadap pembiayaan yaitu jika NPF mengalami kenaikan maka akan berpengaruh pada pembiayaan yang akan mengalami penurunan.

H1 : Dana Pihak Ketiga (DPK) mempunyai pengaruh positif terhadappembiayaan.

H2 : Capital Adequacy Ratio (CAR) mempunyai pengaruh positif terhadap pembiayaan.

H3 : Return on Aseet (ROA) mempunyai pengaruh positif terhadap penyaluran pembiayaan.

H4 : Non Performing Financing (NPF) mempunyai pengaruh negatif terhadap pembiayaan.

\section{METODE PENELITIAN}

Penelitian dilaksanakan pada Tahun 2013 sampai Tahun 2016.melalui penelusuran data di Internet. Jenis penelitian ini adalah deskriptif kuantitatif dimana menurut Nazir (2005) bahwa: Motede deskriptif adalah suatu metode dalam meneliti status kelompok manusia, suatu objek, suatu set kondisi, suatu sistem pemikiran, ataupun suatu kelas peristiwa pada masa sekarang. Sifat penelitian ini adalah deskriptif eksplanatori (penjelasan) dimana menurut Singarimbun dan Effendi (1985) bahwa penelitian penjelasan menyoroti hubungan antara variabel - variabel penelitian dan menguji hipotesis yang telah dirumuskan sebelumnya.

Populasi pada penelitian ini adalah Bank Umum Syariah yang terdaftar pada Bank Indonesia. Adapun alasan pemilihan populasi hanya pada Bank Umum Syariah tidak menyertakan Unit Usaha Syariah dan Bank Perkreditan Rakyat Syariah dalam populasi.

Sampel dipilih dengan metode purposive sampling, yaitu teknik penentuan sampel dengan pertimbangan tertentu. Adapun pertimbangan tersebut berdasarkan kriteriakriteria sebagai berikut: 
1. Memberikan laporan keuangan setiap tahun, secara rutin kepada Bank Indonesia selama periode tahun 2013 sampai tahun 2016.

2. Bank yang tidak dalam kondisi dicabut izin usahanya atau dalam kondisi peralihan kepemilikan.

3. Tersedia variabel data penelitian selama periode pengamatan.

Berdasarkan ketentuan tersebut diketahui bahwa jumlah Bank Umum Syariah yang terdaftar pada Bank Indonesia berjumlah 12 (duabelas) bank.

Ringkasan hasil penyeleksian sampel dapat dilihat pada populasi penelitian Bank Umum Syariah yang memberikan laporan tahunan keuangannya kepada Bank Indonesia. Sejak tahun 2013 sampai 2016 yaitu berjumlah 11 (sebelas) bank. Jadi jumlah data sampel adalah $(11 \times 4=44)$ data sampel yang diambil dari laporan keuangan masingmasing bank selama 4 tahun pengamatan.

\section{Definisi Operasional Variabel}

Dalam penelitian ini terdapat 5 (lima) variabel yang dikelompokkan menjadi dua bagian yaitu variabel terikat (dependent variable) dan variabel bebas (independent variable). Dependen variabel ( $Y$ ) dalam penelitian ini adalah pembiayaan yang disalurkan perbankan syariah, independen variabel (X) yaitu DPK (X1), CAR (X2), ROA (X3) dan NPF(X4).

\section{Alat Analisis}

Metode analisis data yang digunakan dalam penelitian ini adalah dengan metode analisi Regresi Linier Berganda.Dalam melakukan analisis regresi linier berganda, metode ini mensyaratkan untuk melakukan uji asumsi klasik agar mendapatkan hasil regresi yang baik (Ghozali, 2005).

Dalam penelitian ini, data yang telah dikumpulkan dianalisis dengan menggunakan analisis regresi berganda dengan persamaan kuadrat terkecil biasa atau Ordinary Least Square (OLS). Persamaan regresi yang dibentuk adalah sebagai berikut:

I. $Y=\alpha+\beta 1 X 1+\beta 2 X 2+\beta 3 X 3+\beta 4 X 4+e$

Dimana :

$\begin{array}{ll}\mathrm{Y} & =\text { Pembiayaan } \\ \alpha & =\text { konstanta } \\ \beta 1 & =\text { Koefisien regresi DPK } \\ \beta 2 & =\text { Koefisien regresi CAR } \\ \beta 3 & =\text { Koefisien regresi ROA } \\ \beta 4 & =\text { Koefisien regresi NPF } \\ \mathrm{X} 1 & =\mathrm{DPK} \\ \mathrm{X} 2 & =\mathrm{CAR} \\ \mathrm{X} 3 & =\mathrm{ROA} \\ \mathrm{X} 4 & =\mathrm{NPF} \\ \mathrm{e} & =\text { residual }\end{array}$

\section{ANALISISDATA DAN PEMBAHASAN}

\section{Uji Asumsi Klasik}

Dalam pelaksanaan uji asumsi klasik peneliti melakukan beberapa tahapan. Peneliti melakukan transformasi data terlebih dahulu ke dalam bentuk logaritma natural sebanyak dua kali dengan tujuan meminimalkan adanya pelanggaran asumsi normalitas dan linearitas pada model regresi yang disebabkan banyaknya data negatif pada laporan keuangan perbankan syariah dari tahun 2013 - 2016. Uji asumsi klasik pada penelitian ini menggunakan SPSS windows versi 22.0. Dalam pengujian ini terdapat 
empat uji asumsi klasik yang digunakan, adapun hasil pengujian dari masing-masing uji asumsi klasik tersebut adalah sebagai berikut:

\section{Uji Normalitas}

Menurut Gozhali (2012:160) uji normalitas bertujuan untuk menguji apakah dalam model regresi, variabel pengganggu atau residual memiliki distribusi normal.Penelitian ini menggunakan analisis grafik histogram dan grafik normal plot. Berikut ini disajikan Gambar 2 hasil dari uji normalitas analisis grafik histogram melalui program SPSS dengan data yang telah ditransformasi ke dalam bentuk logaritma natural.
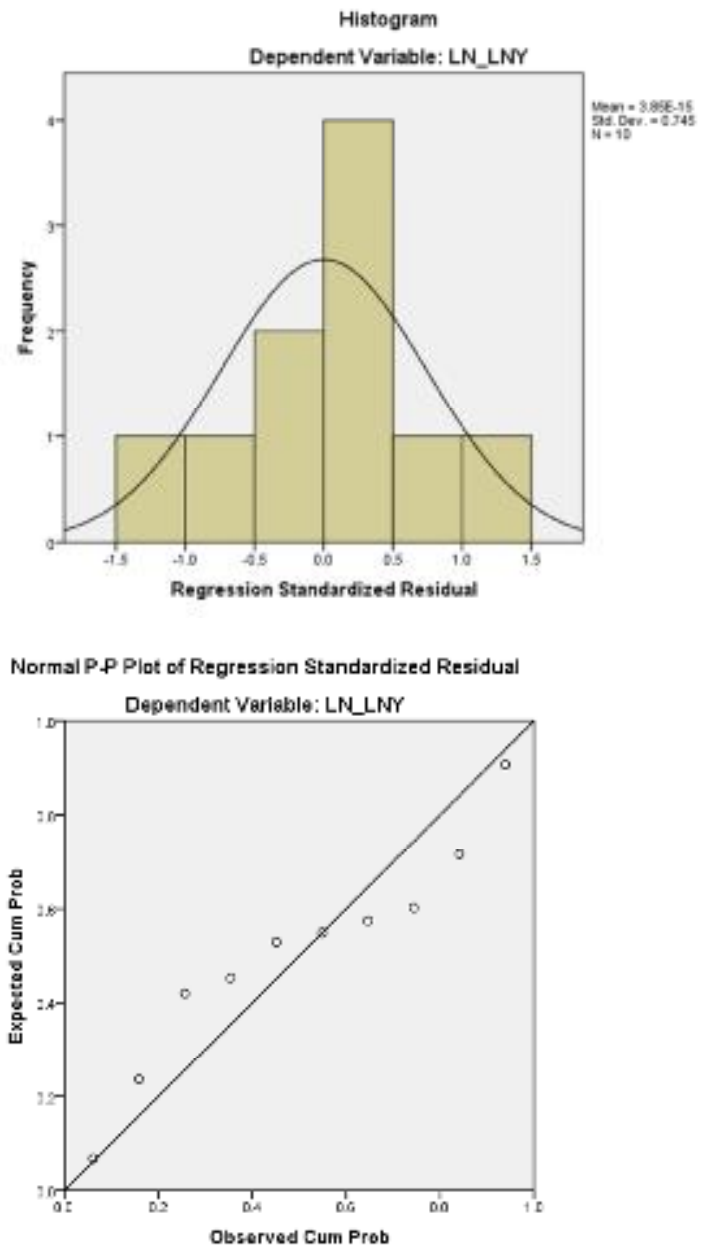

Sumber: Data diolah dengan IBM SPSS 22.0

\section{Gambar 2. Hasil Uji Normalitas dengan grafik histogram dan normal probability plot}

Berdasarkan gambar 2 grafik histogram dan gambar 3 grafik normal plot diatas menunjukan bahwa grafik histogram menggambarkan bentuk menyerupai lonceng. Sedangkan grafik normal plot terlihat titik-titik menyebar di sekitar garis diagonal. Kedua grafik tersebut menunjukan bahwa gambar memenuhi asumsi normalitas.

Uji statistik menggunakan Kolmogorov-Smirnov dilakukan untuk membuktikan apakah data diatas benar-benar berdistribusi normal dimana nantinya akan dapat diambil kesimpulan bahwa kurva nilai residual terstandarisasi memiliki sebaran data normal jika:

- Nilai Kolmogorov-Smirnov Z < Z tabel; atau 
- $\quad$ Nilai Asymp. Sig (2-tailed) $>\alpha$

Berikut ini disajikan Tabel 2 hasil dari Uji Normalitas Kolmogorov-Smirnov melalui program SPSS dengan data telah ditransformasi ke dalam bentuk logaritma natural:

Tabel 1. Hasil Pengujian NormalitasKolmogorov-Smirnov

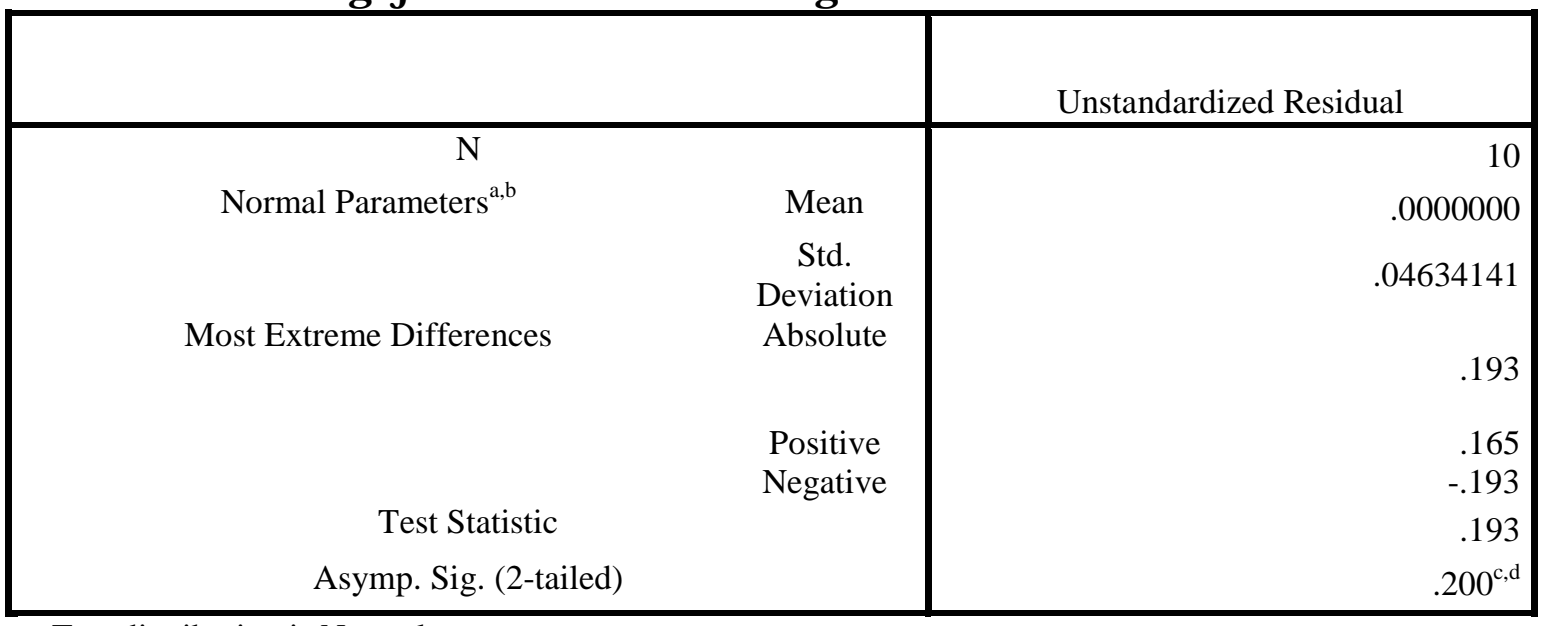

a. Test distribution is Normal.

b. Calculated from data.

c. Lilliefors Significance Correction.

d. This is a lower bound of the true significance.

Berdasarkan tabel 1di atas menunjukan bahwa nilai Kolmogorov-Smirnov sebesar 0.193 dan memiliki nilai tingkat Signifikansi sebesar 0.200. Hal ini menunjukan bahwa nilai signifikansi data tersebut lebih besar dari 0.05 yaitu sebesar $0.200>0.05$. Sehingga dapat disimpulkan bahwa, data tersebut memiliki distribusi normal.

\section{Uji Heterokedastisitas}

Uji heterokedastisitas pada penelitian ini menggunakan metode Scatterplot, yaitu dengan melihat pola titik-titik pada scatterplot regresi. Jika tidak ada pola yang jelas serta titik-titik menyebar diatas dan dibawah angka 0 dan $Y$ maka tidak terjadi heterokedastitisitas.

Berikut ini disajikan Gambar 3 hasil dari uji heterokedastisitas metode Scatterplot melalui program SPSS dengan data telah ditransformasi ke dalam bentuk logaritma natural

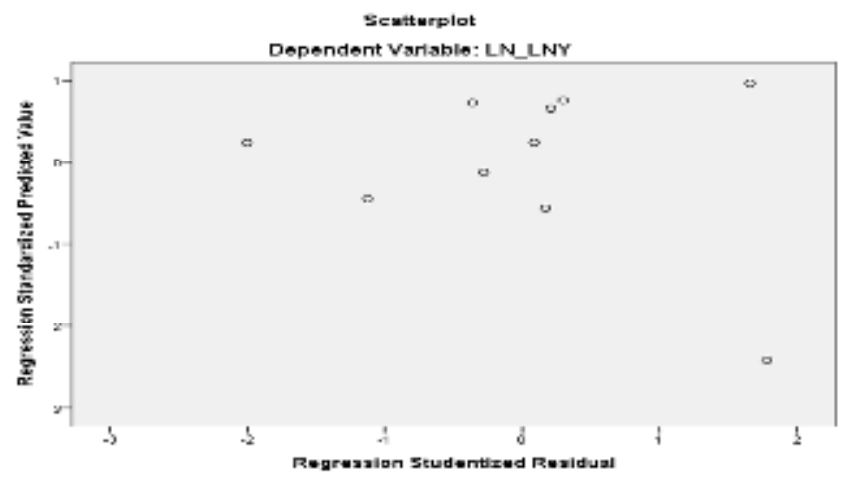




\section{Gambar 3. Grafik Scatterplot}

Dari hasil output uji heterokedastisitas pada Gambar 3tersebut terlihat bahwa titik-titik menyebar dengan gambar pola tidak jelas diatas dan dibawah angka 0 pada sumbu $Y$, dari hasil tersebut maka dapat disimpulkan bahwa tidak terdapat masalah heterokedastisitas pada model regresi.

\section{Uji Multikolonieritas}

Uji Multikolonieritas dilakukan untuk mengetahui apakah model regresi masing-masing variabel bebas (independent) saling berhubungan secara linier.jika dalam model regresi terdapat gejala multikolinieritas, maka model regresi tersebut tidak dapat menaksir secara tepat sehingga diperoleh kesimpulan yang salah tentang variabel yang diteliti.

Ada tidaknya multikolinearitas dilihat dari nilai inflation factor (VIF) dan tolerance pada model regresi. Jika nilai VIF kurang dari 10 dan tolerance lebih dari 0,1 maka model regresi bebas dari multikolinearitas.

Berikut ini disajikan tabel 2 hasil dari uji multikolinearitas metode VIF dan tolerance melalui program SPSS dengan data telah ditransformasi ke dalam bentuk logaritma natural:

\section{Tabel 2. Hasil penelitian Uji Multikolonieritas Variabel Terikat dan Bebas}

\begin{tabular}{|c|c|c|c|}
\hline Variabel Independen & Tolerance & VIF & Keterangan \\
\hline LN_LNX1 & 0.184 & 5.421 & Tidak terjadi Multikolinieritas \\
LN_LNX2 & 0.214 & 4.669 & Tidak terjadi Multikolinieritas \\
LN_LNX3 & 0.696 & 1.437 & Tidak terjadi Multikolinieritas \\
LN_LNX4 & 0.851 & 1.174 & Tidak terjadi Multikolinieritas \\
& & & \\
& & & \\
& & & \\
\hline
\end{tabular}

Sumber : Data Sekunder Diolah

Dari pengujian SPSS diperoleh hasil bahwa kelima variabel memiliki VIF kurang dari 10, yaitu: Dana Pihak Ketiga (Ln-LnX1) dengan nilai VIF 5.421, Capital Adequacy Ratio (Ln LnX2) dengan nilai VIF 4.669, Return On Asset (Ln LnX3) dengan nilai VIF 1.437, Net Performing Financing (Ln_LnX4) dengan nilai VIF $\overline{1}, 174$,

Keempat variabel memiliki nilai tolerance lebih dari 0,10, yaitu: Dana Pihak Ketiga (Ln_LnX1) dengan nilai Tolerance 0.184, Capital Adequacy Ratio (Ln_LnX2) dengan nilai tolerance 0,214, Return On Asset ( $L n \_L n X 3$ ) dengan nilai tolerance 0.696,dan Net Performing Financing (Ln_LnX4) dengan nilai tolerance 0,851.

Dari penjelasan tersebut diketahui bahwa keempat variabel tersebut memiliki nilai VIF kurang dari 10 dan nilai tolerance lebih dari 0,1 maka dapat disimpulkan bahwa model regresi tidak terjadi masalah multikolinearitas.

\section{Uji Autokorelasi}

Berikut ini disajikan tabel 4 melalui program SPSS dengan data telah ditransformasi ke dalam bentuk logaritma natural

Tabel 3. Hasil Penelitian Uji AutokorelasiVariabel Terikat dan Bebas

\begin{tabular}{|c|c|c|c|c|}
\hline Keterangan & Du & DW & $4-D u$ & Interpretasi \\
\hline Nilai & 1.664 & 1.967 & 2.336 & Tidak terdapat autokorelasi positif atau \\
& & & & negatif \\
\hline
\end{tabular}

Sumber : Data Sekunder Diolah 
Berdasarkan data Tabel 3 diketahui bahwa nilai Durbin Watson sebesar 1.967 dengan nilai Du sebesar 1.664. Hal ini menunjukan bahwa nilai DW diantara nilai Du dan 4-Du yaitu sebesar $1.664<1.967<2.336$, sehing ga dapat disimpulkan bahwa tidak terdapat autokerelasi positif atau negatif, dengan kata lain dalam penelitian ini tidak terdapat autokorelasi.

\section{Analis Regresi Linier Berganda}

Persyaratan untuk melakukan metode analisis regresi linier bergandatelah selesai dan sesuai, maka tahapan berikutnya adalah melakukan analisis metode regresi linier berganda.Berdasarkan hasil analisis regresi linier berganda pada program komputer SPSS diperoleh hasil seperti ditunjukkan pada Tabel 4dengan data telah ditransformasi ke dalam bentuk logaritma natural:

\section{Tabel 4. Hasil Analisa BergandaPenelitian}

\begin{tabular}{|c|c|c|c|c|c|c|}
\hline & \multirow[b]{2}{*}{ Model } & \multicolumn{2}{|c|}{$\begin{array}{l}\text { Unstandardized } \\
\text { Coefficients }\end{array}$} & \multirow{2}{*}{$\begin{array}{c}\text { Standardized } \\
\text { Coefficients } \\
\text { Beta }\end{array}$} & \multirow[b]{2}{*}{$\mathrm{t}$} & \multirow[b]{2}{*}{ Sig. } \\
\hline & & B & Std. Error & & & \\
\hline \multirow[t]{5}{*}{1} & (Constant) & .325 & .844 & & .385 & .716 \\
\hline & LN_LNX1 & .681 & .226 & 1.330 & 3.013 & .030 \\
\hline & LN_LNX2 & .388 & .365 & .436 & 1.064 & .336 \\
\hline & LN_LNX3 & .041 & .032 & .290 & 1.274 & .259 \\
\hline & LN_LNX4 & -.015 & .020 & -.150 & -.731 & .498 \\
\hline
\end{tabular}

a. Dependent Variable: LN_LNY

Sumber : Data Sekunder DiolahPengujian Hipotesis Penelitian

Uji hipotesis yang akan dilakukan dalam penelitian ini adalah uji $F$, uji t dan uji $\mathrm{R}^{2}$. Untuk uji yang akan dilakukan adalah sebagai berikut.

\section{Uji F}

Uji $F$ yang dilakukan dalam penelitian ini bertujuan untuk mengetahui apakah model persamaan yang dibuat merupakan model yang fit atau sehat bukan bertujuan untuk menguji hipotesis. Uji ini dilakukan untuk menguji DPK, CAR, ROA dan NPF. Berikut ini disajikan tabel 6 hasil dari uji melalui program SPSS dengan data telah ditransformasi ke dalam bentuk logaritma natural.

Tabel 5. Hasil Uji F Penelitian

\begin{tabular}{|c|c|c|c|c|c|}
\hline \multicolumn{6}{|c|}{ ANOVA $^{a}$} \\
\hline Model & $\begin{array}{l}\text { Sum of } \\
\text { Squares }\end{array}$ & Df & Mean Square & $\mathrm{F}$ & Sig. \\
\hline 1 Regression & .088 & 4 & .022 & 5.705 & $.042^{b}$ \\
\hline Residual & .019 & 5 & .004 & & \\
\hline Total & .108 & 9 & & & \\
\hline
\end{tabular}

a. Dependent Variable: LN_LNY

b. Predictors: (Constant), LN_LNX4, LN_LNX3, LN_LNX2, LN_LNX1

Dari Tabel 5 diperoleh $\mathrm{F}$ hitung sebesar 5.705 dengan nilai sig 0,042 hal ini berarti nilai signifikansi $\mathrm{F}$ kurang dari $<0,05$ maka, artinya variabel bebas dari penelitian yang meliputi DPK, CAR, ROA dan mempunyai pengaruh terhadap pembiayaan perbankan syariah. 


\section{Uji t}

Uji t digunakan untuk mengetahui apakah variabel bebas secara parsial dimaksukkan ke dalam model akan mempunyai pengaruh signifikan terhadap variabel tergantungnya. Dengan nilai signifikan uji $t<0,05$ maka, artinya variabel bebas mempunyai pengaruh terhadap variabel tergantung. Jika nilai signifikan > 0,05, artinya variabel bebas tidak mempunyai pengaruh terhadap variabel tergantung. Berikut ini disajikan tabel 6 hasil dari uji t melalui program SPSS dengan data telah ditransformasi ke dalam bentuk logaritma natural:

\section{Tabel 6. Hasil Uji t}

\begin{tabular}{|c|c|c|c|c|c|c|}
\hline & & & efficients $^{a}$ & & & \\
\hline & \multirow[b]{2}{*}{ Model } & \multicolumn{2}{|c|}{$\begin{array}{l}\text { Unstandardized } \\
\text { Coefficients }\end{array}$} & \multirow{2}{*}{$\begin{array}{l}\text { Standardized } \\
\text { Coefficients } \\
\text { Beta }\end{array}$} & \multirow[b]{2}{*}{$\mathrm{t}$} & \multirow[b]{2}{*}{ Sig. } \\
\hline & & $\mathrm{B}$ & Std. Error & & & \\
\hline \multirow[t]{5}{*}{1} & (Constant) & .325 & .844 & & .385 & .716 \\
\hline & LN_LNX1 & .681 & .226 & 1.330 & 3.013 & .030 \\
\hline & LN_LNX2 & .388 & .365 & .436 & 1.064 & .336 \\
\hline & LN_LNX3 & .041 & .032 & .290 & 1.274 & .259 \\
\hline & LN_LNX4 & -.015 & .020 & -.150 & -.731 & .498 \\
\hline
\end{tabular}

a. Dependent Variable: LN_LNY

\section{Dari Tabel 6 diperoleh hasil :}

\section{a. DPK}

Hasil uji t antara variabel DPK terhadap pembiayaan perbankan syariah menunjukkan nilai 3.013 dengan signifikan sebesar 0,030<0,05, maka dapat disimpulkan bahwa DPK berpengaruh positif signifikan terhadap pembiayaan perbankan syariah. Hipotesis pertama penelitian yaitu Dana Pihak Ketiga (DPK) mempunyai pengaruh positif terhadap pembiayaan bisa diterima.

b. CAR

Hasil uji t antara variabel CAR terhadap pembiayaan perbankan syariah menunjukkan nilai 1.064 dengan signifikan sebesar 0,336>0,05, maka dapat disimpulkan bahwa CAR berpengaruh positif tidak signifikan terhadap pembiayaan perbankan syariah. Hipotesis kedua penelitian bisa diterima, yaitu Capital Adequacy Ratio (CAR) mempunyai pengaruh positif terhadap pembiayaan.

c. ROA

Hasil uji tantara variabel Return On Assets(ROA) terhadap pembiayaan perbankan syariah menunjukkan nilai t hitung sebesar 1.274 dengan nilai signifikan sebesar 0,259> 0,05, maka dapat disimpulakan bahwa Return On Assets(ROA) secara individu berpengaruh positif tidak signifikan terhadap pembiayaan perbankan syariah. Hipotesis ketiga penelitian bisa diterima yaitu Return On Assets(ROA) mempunyai pengaruh positif terhadap pembiayaan.

d. NPF

Hasil uji t antara variabel Non Performing Financing (NPF) terhadap pembiayaan perbankan syariah menunjukkan nilai sebesar $(-0,150)$ dengan nilai signifikan sebesar 0,498> 0,05, maka dapat disimpulkan bahwasecara individu Non Performing Financing (NPF) berpengaruh negative tidak signifikan terhadap pembiayaan perbankan syariah. Hipotesis keempat dari penelitian bisa diterima yaitu Non Performing Financing (NPF) mempunyai pengaruh negatif terhadap pembiayaan. 


\section{3. $\quad \mathbf{j j i} \mathbf{R}^{2}$}

Uji $\mathrm{R}^{2}$ pada intinya mengukur seberapa jauh kemampuan model dalam menerangkan variasi variabel dependen. Nilai koefisien determinasi adalah antara nol dan satu. Nilai $R^{2}$ yang kecil berarti kemampuan variabel-variabel indenpenden dalam menjelaskan variasi variabel dependen amat terbatas. Berikut ini disajikan tabel 7 hasil dari uji $R^{2}$ melalui program SPSS dengan data telah ditransformasi ke dalam bentuk logaritma natural:

\section{Tabel 7. Hasil Uji $\mathbf{R}^{2}$}

Model Summary

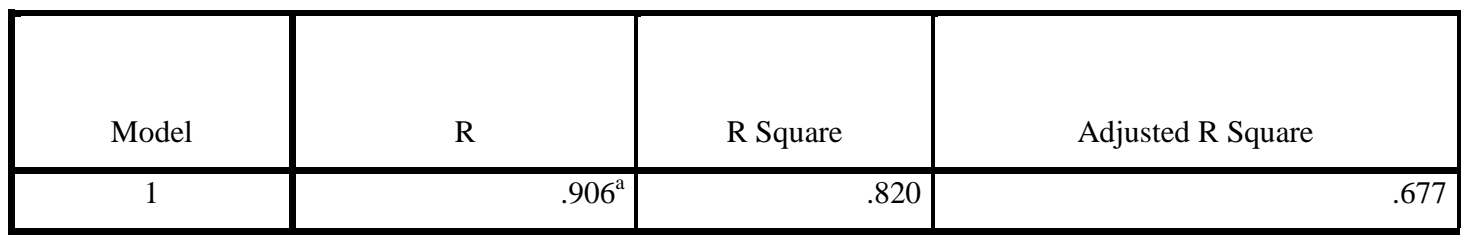

a. Predictors: (Constant), LN_LNX4, LN_LNX3, LN_LNX2,

LN_LNX1

Berdasarkan dari Tabel 7 diatas didapat nilai $\mathrm{R}^{2}$ adalah 0,820 , hal ini berarti bahwa 0,820 \% variabel pembiayaan dapat di jelaskan oleh variabel independen DPK, CAR, ROA dan NPF, sedangkan sisanya sebesar $5 \%$ di jelaskan variabel yang lain.

\section{Pembahasan}

\section{Variabel X1 Dana Pihak Ketiga (DPK)}

Dalam penelitian ini nilai koefisien DPK adalah positif ini menunjukkan bahwa semakin meningkat DPK maka pembiayaan semakin meningkat. Hasil penelitian ini sesuai dengan penelitian Olokoyo (2011) yang menunjukkan bahwa deposito bank komersial memiliki dampak terbesar pada penyaluran pinjaman. Meningkatnya DPK mengakibatkan naiknya pembiayaan menunjukkan bahwa fungsi intermediasi perbankan berjalan dengan baik dimana fungsi perbankan dengan menghimpun dana dari pihak ketiga dan menyalurkan kembali kemasyarakat atau pihak yang membutuhkan dalambentuk pembiayaan.

\section{Variabel X2 Capital Adequacy Ratio (CAR)}

Dalam penelitian ini nilai koefisien CAR adalah positif yang menunjukkan bahwa semakin meningkat CAR maka pembiayaan semakin meningkat. Hasil penelitian sesuai dengan penelitianMaharani (2010) yang menyatakan bahwa CARberpengaruh positif dan signifikan terhadap penyaluran pembiayaan, dan menolak hasil penelitian penelitian Olokoyo (2011) yang menyatakan bahwa rasio likuiditas tidak berpengaruh terhadap penyaluran pinjaman.

\section{Variabel $X 3$ Retum On asset (ROA)}

Dalam penelitian ini nilai koefisien ROA adalah positif yang menunjukkan bahwa semakin meningkat ROA maka pembiayaan akan bertambah. Hasil penelitian ini seusai dengan hasil penelitian Yoga Pradana dan R. Djoko Sampurno (2013) yang menyatakan ROA mempunyai pengaruh yang positif dan signifikan terhadap volume KPR.

\section{Variabel $X 4$ Net Performing Financing (NPF)}


Dalam penelitian ini nilai koefisien NPF adalah negatif yang menunjukkan bahwa semakin meningkat NPF maka pembiayaan semakin menurun. Meningkatnya NPF disebabkan kenaikan pembiayaan yang bermasalah sehingga perbankan syariah berhati-hati untuk mengeluarkan pembiayaan yang dikeluarkannya untuk meminimalkan timbulnya pembiayaan bermasalah. Hasil penelitianini sesuai dengan penelitian yang dilakukan oleh Pratama (2010) danTenrilau (2012) yang menyimpulkanbahwa NPF berpengaruh negatifterhadap pembiayaan

\section{SIMPULAN}

Penelitian ini mencoba untuk menganalisa faktor-faktor yang mempengaruhi pembiayaan pada perbankan syariah di Indonesia.Sampel yang digunakan dalam penelitian ini adalah semua populasi Bank Umum Syariah yang berjumlah 11 Bank UmumSyariah. Karena dalam penelitian ini mencoba menggunakan data time series dari laporan keuangan maka sampel menjadi 11 Bank Umum Syariah dari 132 Bank Umum Syariah selama empat tahun. Variabel yang digunakan dalam penelitian ini adalah Pembiayaan, Dana Pihak Ketiga (DPK), Capital Adequacy Ratio (CAR), Return On Assets(ROA)danNon Performing Financing (NPF). Dari analisia dan pembahasan yang telah dilakukan atas hasil penelitian pada bab sebelumnya, maka dapat diambil kesimpulan sebagai berikut:

1. Berdasarkan hasil pengujian hipotesis melalui uji Fyang dilakukan menyatakan bahwa semua variabel bebas (independen) yang terdiri dari Dana Pihak Ketiga (DPK), Capital Adequacy Ratio (CAR), Return On Assets(ROA) danNon Performing Financing (NPF) berpengaruh signifikan terhadap pembiayaan Bank UmumSyariah. Hal tersebut dapat diketahui nilai dari uji $\mathrm{F}$ lebih kecil dari nilai signifikan berada diatas alpha 0,05.

2. Berdasarkan hasil pengujian hipotesis melalui uji t didapatkesimpulan bahwa :
a. Hipotesis pertama penelitian yaitu Dana Pihak Ketiga (DPK) mempunyai pengaruh positif terhadap pembiayaan bisa diterima.
b. Hipotesis kedua penelitian bisa diterima, yaitu Capital Adequacy Ratio (CAR) mempunyai pengaruh positif terhadap pembiayaan.
c. Hipotesis ketiga penelitian diterima yaitu Return On Assets(ROA) mempunyai pengaruh positif terhadap pembiayaan di karenakan thitung bernilai positif.
d. Hipotesis keempat dari penelitian yaitu Non Performing Financing (NPF) mempunyai pengaruh negatif terhadap pembiayaan diterima.

\section{Keterbatasan Penelitian}

Penelitian ini memiliki beberapa keterbatasan yang apabila dapat diatasi pada penelitian selanjutnya akan memperbaiki hasil penelitian. Beberapa keterbatasan dari penelitian ini adalah:

1. Jumlah sampel yang diteliti masih sedikit disebabkan populasi Bank Umum Syariah yang terbatas dan periode penelitian dalam penelitian ini hanya terbatas selama 2013 sampai dengan 2016. Sehingga memungkinkan adanya ketidakakuratan pada hasil penelitian.

2. Dalam penelitian ini hanya meneliti lima variabel bebas yaitu Dana Pihak Ketiga (DPK), Capital Adequacy Ratio (CAR), Return On Assets (ROA), Non Performing Financing (NPF) dan Ukuran Perusahaan dan satu variabel terikat yaitu Pembiayaan.

3. Dalam penelitian ini data banyak ROA banyak yang bernilai negatif, maka dilakukan trasformasi data ke dalam Logartiman Natural dengan tujuan meminimalkan adanya pelanggaran asumsi normalitas dan linearitas pada model 
regresi, sehingga uji outlier tidak dilakukan pada penelitian ini, dikarenakan sampel data yang akan di outliner terlalu sedikit.

\section{Saran}

Berdasarkan hasil penelitian serta kesimpulan yang telah diuraikan maka peneliti menyarankan :

1. Dalam penelitian selanjutnya diharapkan agar jumlah sampel dapat ditambah menjadi lebih banyak dengan menggabungkan populasi Bank Umum Syariah dengan Unit Usaha Syariah atau semua perbankan syariah di Indonesia. Hal ini dimaksudkan agar diperoleh hasil yang lebih akurat.

2. Penelitian yang akan datang hendaknya menambah variabel penelitian tidak hanya dari faktor internal tetapi faktor eksternal perbankan sehingga dapat memnetahui faktor-faktor yang mempengaruhi pembiayaan Bank Umum Syariah.

\section{DAFTAR PUSTAKA}

Dahlan Siamat. 2004. Manajemen Lembaga Keuangan. FE Universitas Indonesia, Jakarta.

Dendawijaya, Lukman, 2005. Manajemen Perbankan, Edisi Kedua, C etakan Kedua, Ghalia Indonesia, Bogor Jakarta.

Donna, Duddy Roesmara dan Nurul Chotimah. 2008. " Variabel-variabel Yang Mempengaruhi Pembiayaan Pada Perbankan Syariah Di Indonesia Ditinjau Dari Sisi Penawaran". Jurnal Ekbisi Vol 2, No. 2, Halaman 19.

Ghozali, Imam, 2005, Aplikasi Analisis Multivariate dengan Program SPSS, Badan Penerbit Universitas Diponegoro, Semarang.

Haryati, Sri. 2009. "Pertumbuhan Kredit Perbankan di Indonesia: Intermediasi dan Pengaruh Variabel Makroekonomi". Jurnal Keuangan dan Perbankan, Vol. 13, No. 2, hal. 299-310. .

Hasanudin, Mohammad dan Prihatiningsih, 2010. "Analisis Pengaruh DPK, Tingkat Suku Bunga Kredit, NPL, dan Tingkat Inflasi Terhadap Penyaluran Kredit Bank Perkreditan Rakyat (BPR di Jawa Tengah)". TEKNIS Vol. 5 No. 1. Pp : 25-31.

Ladime, Sarpong-Kumankoma, O sei. 2013 "Determinants of Bank Lending Behaviour in G hana" Journal of Economics and Sustainable Development Vol.4, No.17, pp: 42-47.

Lifstin Wardiantika,. 2013. "Pengaruh Dpk, Car, Npf, Dan Swbi Terhadap Pembiayaan Murabahah Pada Bank Umum Syariah Tahun 2008-2012" Jurnal IImu ManajemenVol. 1, No. 6, pp: 1550-1561.

Olokoyo. 2011. "Determinants of Commercial Banks' Lending Behavior in Nigeria"International Journal of Financial Research Vol. 2, No. 2, pp: 61-72.

Pratama, Billy Arma. 2010."Analisis Faktor-Faktor Yang Mempengaruhi Kebijakan Penyaluran Kredit Perbankan (Studi Pada Bank Umum di Indonesia Periode tahun 2005-2009)" .Tesis Program Studi Manajemen Universitas Diponegoro.

Pratin dan Akhyar Adnan. 2005. "Analisis Hubungan Simpanan, Modal Sendiri,NPL, Prosentase Bagi Hasil dan Markup Keuntungan terhadap Pembiayaan pada Perbankan Syariah (studi kasus pada BMI)".Sinergi Kajian Manajemen dan Bisnis, Edisi Khusus on Finance. Hal 35-52

Saidi, 2004, "Faktor-Faktor yang Mempengaruhi Struktur Modal pada Perusahaan Manufaktur Go Public di BEJ Tahun 1997-2002", Jurnal Bisnis dan Ekonomi, Vol.11, No.1, Maret, Hal 44-58.

Siswati,. 2013. "Analisis Penyaluran Dana Bank Syariah" Jurnal Dinamika ManajemenVol. 4, No. 1, pp: 82-92. 
SAK Nomor 31 dalam Standar Akuntansi Keuangan tahun 2009 (revisi 2000).

Yoga Pradana dan R. Djoko Sampurno. 2013. "Analisis Pengaruh LDR, CAR, ROA dan Faktor Eksternal Perbankan Terhadap Volume KPR Pada Bank Persero (2008-2012) di Indonesia". Diponegoro Journal Of Management, Vol. 2, No. 3, pp: 1-10.

Republik Indonesia. 1998. Undang - Undang No. 10 Tahun 1998 tentang perubahan Undang - Undang No. 7 Tahun 1992 tentang Perbankan. Sekretariat Negara. Jakarta.

Republik Indonesia. 1999. Undang - Undang No. 23 Tahun 1999 tentang Bank Indonesia. Sekretariat Negara. Jakarta.

Republik Indonesia. 2008. Undang - Undang No. 21 Tahun 2008 tentang Perbankan Syariah. Sekretariat Negara. Jakarta 